\title{
Correction to: Follow-up evaluation of the immunological status of children admitted for acute cerebral nervous system infections: a retrospective study.
}

Giulia Spina ${ }^{1 *}$, Elena Bozzola ${ }^{1}$, Rita Carsetti ${ }^{2}$, Eva Piano Mortari ${ }^{2}$, Cristina Mascolo ${ }^{1}$, Marco Roversi ${ }^{1}$ and Alberto Villani ${ }^{1}$

Following the publication of the original article [1], the authors identified an error in the author names of Elena Bozzola, Rita Carsetti, Eva Piano Mortari, and Alberto Villani. The given name and family name were erroneously transposed.

The incorrect author names are: Bozzola Elena, Carsetti Rita, Piano Mortari Eva and Villani Alberto.

The correct author names are: Elena Bozzola, Rita Carsetti, Eva Piano Mortari, and Alberto Villani.

The author group has been updated above and the original article [1] has been corrected.

\footnotetext{
Author details

${ }^{1}$ University/Hospital Department of Pediatrics, Pediatric and Infectious Diseases Unit, Bambino Gesù Children's Hospital, IRCCS, Rome, Italy. ${ }^{2}$ B cell Physiopathology Unit, Immunology Research Area,Bambino Gesù Children Hospital, Rome, Italy.
}

Published online: 29 October 2021

\section{Reference}

1. Spina G, et al. Follow-up evaluation of the immunological status of children admitted for acute cerebral nervous system infections: a retrospective study. Ital J Pediatr. 2021;47:22. https://doi.org/10.1186/s13052-021-00973-1.

The original article can be found online at https://doi.org/10.1186/s13052021-00973-1.

* Correspondence: giulia.spina@opbg.net

${ }^{1}$ University/Hospital Department of Pediatrics, Pediatric and Infectious Diseases Unit, Bambino Gesù Children's Hospital, IRCCS, Rome, Italy

Full list of author information is available at the end of the article

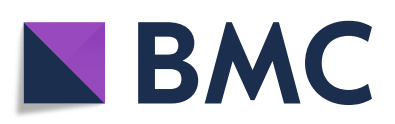

(c) The Author(s). 2021 Open Access This article is licensed under a Creative Commons Attribution 4.0 International License, which permits use, sharing, adaptation, distribution and reproduction in any medium or format, as long as you give appropriate credit to the original author(s) and the source, provide a link to the Creative Commons licence, and indicate if changes were made. The images or other third party material in this article are included in the article's Creative Commons licence, unless indicated otherwise in a credit line to the material. If material is not included in the article's Creative Commons licence and your intended use is not permitted by statutory regulation or exceeds the permitted use, you will need to obtain permission directly from the copyright holder. To view a copy of this licence, visit http://creativecommons.org/licenses/by/4.0/ The Creative Commons Public Domain Dedication waiver (http://creativecommons.org/publicdomain/zero/1.0/) applies to the data made available in this article, unless otherwise stated in a credit line to the data. 